\title{
THE ABSENCE AND PRESENCE OF GOD IN THE BOOK OF EXODUS AS THEOLOGICAL SYNTHESIS ${ }^{1}$
}

\author{
Hendrik Bosman \\ Department of Old and New Testament \\ Stellenbosch University
}

\begin{abstract}
This article argues that divine presence and absence plays an important role in the narratives of the book of Exodus. A dialectic between divine presence and absence is indicated by the use of the expression the "fear of God/the Lord" in Exodus. The article argues that "the fear of the Lord/God" provides a window into the process of establishing theological coherence in the book of Exodus where contending theological traditions were brought together as an initial overture towards the eventual canonisation of the Torah, Prophets and the Writings.
\end{abstract}

\section{Introduction}

\subsection{Research Survey}

1.1.1 Pentateuch - During the first last decade of the twentieth century Pentateuch watchers have detected a shift in research emphasis which "may be characterized as a movement from a diachronic (historical) reading of the text to a synchronic (non historical) reading" (Campbell \& O'Brien 1993:15). This initial movement from diachronic to synchronic seemed to have evolved in subsequent years into a symbiosis of diachronic and synchronic readings of the Pentateuch (Vervenne 1996:5).

While most scholars agree to the existence of D and P traditions in the Pentateuch, only some also maintain that some form of J tradition survived (van Seters 1994).

Eckart Otto (1996:111) has suggested a post-Priestly redaction of the Pentateuch which linked existing Deuteronomic and Priestly traditions in the time of Ezra during the so-called Persian "Reichsautorisation" by combining the Sinai theophany, the Torah and the figure of Moses. Hans-Christoph Schmitt (1997:278-279) proposes a "late Deuteronomistic History" by the scribes that struck a post-exilic compromise between priests and prophets by redefining Moses as a prophet and thereby achieving canonical coherence between Torah and Nebiim (see also Houtman 1994:441-446).

After being overwhelmed by what has been published on the Tetrateuch /Pentateuch/ Hexateuch problem, I have decided to presuppose the existence of different theological traditions during and soon after the Exile. It seems to me less important what label I attach to them: a single or redaction ally expanded Deuteronomistic tradition with a strong historical orientation and prophetic interest - with the spectre of the Yahwist hovering in the background; and a Priestly tradition with an obvious cultic bias. But, this redactional combination of Deuteronomistic and Priestly traditions does not yet explain the sapiential influence I seem to detect when I am confronted by the dialectic of the presence and the absence of God in the book of Exodus. I therefore suggest the possible sapiential supplementation of the combined D and P traditions and would argue for a theological coherence similar to the so-called "later wisdom".

1. The generous financial support of the $C S D / N R F$ is acknowledged that made the research required for this article possible. 
1.1.2 The book of Exodus - Against this backdrop of current Pentateuchal research it does not come as any surprise that very little consensus has been reached about the final redaction of the book of Exodus or about the process during which D and P material (and even J) were unified into a more or less coherent text.

In a thematic study of Exodus, Frank Polak (1996:147) shies away from linking his proposals about thematic unity in the book of Exodus, what he depicts as the "unfolding" theophany, with any particular source, tradition or redaction; he did not consider the possibility of sapiential influence.

\subsection{Problem and Hypothesis}

The foremost questions I am addressing in this article are: Do we find reference to divine presence and absence in Exodus? If so, how do you explain the relatedness of the presence and absence of God in the book of Exodus? I would like to suggest that the association between Torah and Wisdom, which is clearly presupposed by Sirach at the beginning of the second century BCE, can be linked to the use of the expression "fear of God/the Lord". The relationship of divine absence and presence in the book of Exodus can be explained as a dialectic that enables coherence between contending theological traditions.

The article consists of "work/research in progress" which presuppose a working hypothesis that suggests a link between the finalizing of Exodus as a book and the relating of Torah and Wisdom by a theological synthesis that combined existing theological traditions (D and P; even J!). I am therefore interested in the possibility that sapiential influence played an important facilitating role in the post-exilic period by creating more theological coherence between the existing theological (Deuteronomistic and Priestly?) traditions. It would seem as if the concept "fear of God/the Lord" provides a window into the process of establishing theological coherence in the book of Exodus as part of the Pentateuch/ Hexateuch and of the initial overture towards the canonisation of the Torah, Prophets and the Writings.

\section{Presence and Absence of God}

\subsection{General Research Trends}

My survey of the research on the theme, the presence of God in the Old Testament, comes to a similar conclusion as Henton Davies (1962:857) almost forty years ago:

The material of the presence theme is so complex, and the media of manifestation so varied, that attempts to trace various stages in the development of the doctrine (sic) have not been successful.

It also seems futile to attempt the reconstruction of a unilinear development of the concepts suggesting the presence or absence of God and rather allow for the possibility for the coexistence of different metaphors related to this topic (Davies 1962:875).

Far less attention has been given in scholarly research to the absence of God in the Old Testament. In most of the discussions of the "presence of God" some passing reference is made about the "absence of God". In a certain sense it is inevitable to assume absence when you refer to divine presence, since synecdoche as a type of pars pro toto reference to God, frequently ends up as a reference to "presence-in-absence" (Davies 19962:875).

The terminology used for the "presence of God/the Lord" includes nouns such as face, glory, name, tabernacle; prepositions such as "before/in the face of"; and "in the midst of" or "with". Several verbs are also used of which sgn "to dwell" is the most important (Davies 1962:874). Mann (1977:252-258) compiled a glossary of terms which focuses on 
the verbs in the Old Testament "with divine subject which express divine presence or appearance" and I shall briefly refer to those that occur in the book of Exodus:

- $\quad b w^{\prime}$ ' ("come") This verb is rarely used in the Pentateuch and in Exodus it is clustered in the description of the Sinai theophany (19:9; 20:20, 24); also in Exod 14:24;

- hlk ("to do away, depart") As part of the expression hlk lpny it is used frequently in the narratives about the journey through the Wilderness (Exod 13:21; 14:19; 23:23; 32:1, 23, 34). In Exod 33:14-16 the subject is Yahweh's pnym, Yahweh himself, which seems to be followed by $34: 9$;

- $y s$ ' ("go out from") is rarely used with God as subject and more frequently with divine agents. The deliverance from Egypt is described in Exod 11:4 by using ys';

- $y r d$ ("come down, descend") is used in Exod 3:8 in connection with divine judgement or deliverance, as well as the phenomena of fire or cloud $(19: 11,18,29 ; 33: 9)$;

- $\quad n h h$ ("lead") refers to divine protection and guidance $(13: 17,21 ; 15: 13 ; 32: 34)$. It is also often used with the connotation of instruction and further research is needed to ascertain possible wisdom influence;

- ' $b r$ ("passing over") and is usually combined with lpny;

- 'Ih ("before") is used extensively in deuteronomistic and prophetic materia. In Exodus it is used with a complaint of the people $(32: 1,23)$;

- panim ("face, presence") is used in Exod 33:14015 in the phrase "face to face" as an expression of intimacy;

- $\quad r$ 'h ("leave") is used as the reverse of $b w$ ' and usually communicates divine judgement during a crisis situation.

There is difference of opinion about the inclusion of references to epiphanies, theophanies and the omnipresence of God in the discussion about the presence and absence of God Henton Davies (1962:874) says no; while Mann (1977:233) includes them.

My survey of research related to the presence and absence of God indicates a methodological development from a form-critical and traditio-historical approach (von Rad, Beyerlin), to a History-of-religions approach (Mendenhall, Cross, Mann) and a literary and cultic-historical approach (Dozeman).

The research survey also suggests different themes in the interpretation of the presence and absence of God:

- Henton Davies (1962:874) the "tabernacling presence";

- Moshe Weinfeld (1972b:1015-1018) distinguishes between a corporeal sense of divine presence in the Priestly references to the kabod of the Lord in the ark and the tabernacle, the cherubim and the cloud; and an abstract notion reflected in the Deuteronomic/ deuternomistic symbolic representation of the divine presence in the Name (so-called śem theology);

- Walter Brueggemann (1976:680) traces a development in the cultic presence of God characterised by the ongoing tension or polarity between the freedom and the accessibility of YHWH as the Holy One: during the Sinai period God has a powerful or "coming" presence; whilst in the time of the wanderings He is the "nourishing and leading" presence; in the time of the monarchy He is the "abiding" presence and during the exile He becomes the "hidden" presence;

- Thomas Mann (1977:239) tried "to demonstrate the significant correspondence between the form and function of motifs of divine presence in the Old Testament and the ancient Near Eastern texts, but also to take seriously the ways in which the Old Testament reflects Israel's peculiar historical and religious experience." He points out 
how divine presence in the Old Testament incorporates "guidance" for the individuals and Israel as a whole; and how divine presence occurs in conjunction with the "exaltation" of religious leaders such as Moses (Exodus $3-4 ; 14 ; 19$ ) and kings such as Solomon (1 Kings 1; 8);

- Samuel Terrien (1978) suggested in the title of his attempt at a Biblical theology, The Elusive Presence, an acute awareness that any study of the presence of God must take the divine absence seriously. However, his overwhelming sense of the cultic presence of God in the Old Testament did not allow him to do justice to the divine absence (Gowan 1994:7);

- Samuel Balentine (1983) did an excellent study of the expression, "the hiding of God's face", and it is significant that he found about one half of the occurrences of this experience of divine absence in the psalms of lament;

- John Durham (1987) wrote his Word Commentary on Exodus as a book that has a distinct theological purpose and coherence. The "presence of Yahweh" is the "centrepiece" of this postulated theological unity "serving as a theological anchor and ... compass" (Durham 1987:xxi). Durham, taking the presence of God as point of departure, identifies in the Book of Exodus a series of interlocking concentric circles developing from the experience of God's presence by Moses in Exod 3 and 4, to all Israel in chapters 19, 20 and 24. He also refers to the representation of God by Moses in chapters 32, 33 and 34. In his initial discussion of the presence of God (p.xxi) almost no reference is made of the plague and wilderness narratives. Paying some attention to the plagues that had to convince first Moses, then the Israelites, the Egyptian people, the Egyptian court and finally the mighty Pharaoh himself later rectifies this;

- Another aspect of the Exodus narrative's definition of the presence of God is its ongoing orientation with regards to the past and the future. In Exod 3 and 4 references is made of God's presence in Egypt during the time of the patriarchs (especially Joseph) and towards the future by anticipating the proving of his powerful presence to Israelites and Egyptians alike. In a similar vein Exod 19-20 refers back to God's presence in Egypt and at the sea, whilst Israel's response to his presence is anticipated $(19: 5-6 ; 2): 3-17)$;

- Although Durham (1987:17) admits that the lack of references to God in Exodus 1-2 was intentional, he does not pursue the topic of God's absence any further;

- Terrence Fretheim (1991:20-21) identifies "Israel's worship and Yahweh's presence" as some of the important theological issues in his Interpretation Commentary on Exodus. He detects a "movement in Exodus from seeming divine absence to the fullness of presence in the tabernacle" (Fretheim 1991:21).

\subsection{The Writings}

Any discussion of the Ketubim on the topic of divine presence must keep in mind that according to the post-biblical Jewish theological understanding, the sekinah or divine presence, was in fact absent from the Second Temple, i.e. the presence became an absence! (Davies 1962:875).

\subsection{The Prophets}

Numerous references to the presence of God in the temple, directly or indirectly, can be found in the prophets (Amos 1:2; Hos 5:15; 11:9; Mic 1:2-3; Isa 6:1-5; 30:27-29; Jer 7:1215; Ezek 8:6). 
In some of the prophetical allusions to divine presence there seems to be an eschatological expectation of the future manifestation of the presence of God - which of course implies an experience of absence in the time of the prophets (Ezek 37:26-28; 43:1-2; Joel 3:17,21; Zeph 3:15; Zech 2:10-11; Mal 3:1).

\subsection{The Torah}

The enigmatic 'ehyeh 'aser 'ehyeh in Exodus 3 is a phrase that echoes the assurance "I will be with you" in 3:12 and communicates "something about presence and assistance in the uncertain events about to unfold" (Blenkinsopp 1992:149).

It is interesting that almost no scholarly attention has been given to the possibility of wisdom thought having at least some influence on how the presence and absence of God was understood in the book of Exodus. Neither has there been any discussion of "fear of God/the Lord" as a reference to the presence and absence of God.

\section{The "Fear of God/The Lord" as Expression of Presence and Absence and as Possible Indicator of Wisdom Influence}

\subsection{Research Trends}

James Crenshaw (1969:129) commented on the increasing emphasis of the "influence of wisdom" upon "non-hagiographic literature" and cautioned that one should be clear about the method and concepts used during the arguments for indicating "wisdom influence". These cautionary comments are as valid today as they were some thirty years ago since exaggerated claims and dubious assumptions about "wisdom influence" are still very much alive! It boils down to the following question: How do you determine wisdom influence upon historical literature?

Wisdom must be defined and it is clear that a distinction must be made between (Crenshaw 1969:130-132):

- Wisdom literature (Proverbs - Wisdom of Solomon);

- Wisdom movement (sapiential curriculum and pedagogy in the family or clan and scribes);

- Wisdom thinking (approach to reality which searches for meaning in terms of nature, practical experience and the existence of God).

In my particular argument special attention will be paid to a trend in "theological wisdom" which moves beyond theodicy and "affirms God as ultimate meaning", even when it is futile to grasp the purpose of life (Crenshaw 1969:132).

Besides the definition of "wisdom", stylistic or ideological peculiarities found in wisdom literature must be pointed out before any claim to "wisdom influence" can be made. That is the reason why I focus on the term "fear of God/the Lord" and the association between this concept as the essence of wisdom and the Torah as instruction. Here close attention must be paid to the possibility that different nuances can be detected when wisdom phrases or motifs are used outside of wisdom literature. (The scope of this article does not allow me to do justice to this requirement and will have to be researched more thoroughly in future.)

In general the historical development of wisdom, insofar as it can be reconstructed, and the negative attitude towards wisdom in the Old Testament, must be kept in mind. I would like to argue in this contribution that wisdom's concern with the Torah and narratives 
connected to Israel's memory of God's mighty deeds in the past can be traced earlier than the usual late post-exilic period.

Katharine Dell (1997:136) provides several reasons for the neglect of wisdom literature and theology when Old Testament theology and the development of the Pentateuch are discussed. One of the most important reasons for this neglect is the "now dated view" of the development of wisdom as a linear progression from family to court or school wisdom or that creation was a rather late theological topic.

\subsection{The Writings}

Any reflection about the concept "the fear of God" in the post-exilic period must take into consideration the crucial role it played in the book of "The Wisdom of Ben Sira" and I would like to argue that it is also pertinent to the discussion of Exodus and the understanding of the Torah.

Although there has been some disagreement about the primary theme of Ben Sira, Haspecker (1967:87-105) opting for the "fear of the God" and Marbock (1971) settling for wisdom in general, I would agree with Skehan and Di Lella (1987:75-76) that it is all about "wisdom as fear of God" since "wisdom, which is identified with the Law, can be achieved only by one who fears God and keeps the commandments":

The whole of wisdom is fear of the Lord;

and in all wisdom there is the fulfilment of the law (19:20)

Some text variants add: "and the knowledge of his omnipotence."

Not only is there a clear statistical preference for the expression "fear of God' in Ben Sira (56-60 times) (and also in the Psalms [79 times]) but there is also a detailed discussion on wisdom as fear of God in the programmatic introduction of Ben Sira (1:1-2:18). Here the "fear of the Lord" is the "beginning and "root" of wisdom $(1: 14,20)$ and reflects the essence of sapiential theological reflection, and it seems significant that a close relationship exists between "fear of God", wisdom and Torah:

Whoever fears the Lord will do this,

and whoever holds to the law

will obtain wisdom (15:1)

Those who survive her will

recognize

that nothing is better than the

fear of the Lord,

and nothing sweeter than to heed

the commandments of the Lord (23:27).

Sirach "stops short of an outright equation" of wisdom and the fear of the Lord, but it is virtually synonymous; and the observance of the commandments becomes one of its manifestations (Collins 1997:46-47).

According to Ben Sira, those who "fear God" will know "they have a personal relationship with God, by their faith, hope and confidence in him and by their obedience to him" (Skehan \& Di Lella 1987:79-80).

Similar theological convictions seem to be reflected in the epilogue to Qoheleth (12:13):

"The end of the matter: all has been heard. Fear God, and keep his commandments; for that is the whole duty of everyone". 
In his excellent commentary on Ecclesiastes, CL Seow (1997:394-356) points to the fact that the concept of "fear of God" is present in the teachings of Qoheleth $(3: 14 ; 5: 6 ; 8: 12$ 13); but that the "call to obey God's commandments is not" and that this perspective in the epilogue "seems to be different from the rest of the book." The call to obedience to divine commandments is not contradictory to the book as a whole, but it might constitute "a hermeneutic move that assured the acceptance of Ecclesiastes into the canon" (Seow 1997:396).

In the older part of the book of Proverbs, the admonitions of chapters 10-29, "the fear of the Lord" can be described "as a comprehensive description of the way of life ... which the wisdom teachers wished to inculcate" (Clements 1992:60-62).

"The fear of the Lord is

instruction in wisdom,

and humility goes before honor" (15:33);

"The fear of the Lord is life indeed" (19:23);

"The reward for humility and fear of the Lord

is riches and honor and life" (22:4; similar also $23: 27 ; 24: 21 ; 28: 5,14 ; 31: 30)$.

In the younger wisdom of the introductory poems of Proverbs 1-9, the concept "the fear of the Lord" is probably used as an inclusio:

"The fear of the Lord is the beginning of knowledge;

fools despise wisdom and instruction." (1:7)

"The fear of the Lord is the beginning of wisdom,

and the knowledge of the Holy One is insight" (9:10)

Clements (1992:62) is of the opinion that the "fear of the Lord" here is identified "as the springboard for right conduct" and that it represents "a desire to please the Lord Yahweh in all things and to give respect to the divine order of social and moral life".

Von Rad's influential article on the influence of wisdom in the Joseph narrative lead to similar claims made about the book of Esther (Crenshaw 1967:129). Without going into a detailed discussion of Talmon's (1963:419-455) article on the wisdom influence in Esther and agreeing with his depiction of the book's genre as "historicized wisdom tale", he did succeed in pointing out significant similarities with other Old Testament traditions not usually connected to it (Morgan 1981:125).

\subsection{The Prophets}

A good case can be made to trace wisdom influence in Malachi; i.e. the proverbial type saying in 1:6 where reference is made to the "fear" due to a master (Morgan 1981:122123). Further mention is made of the "fear of the Lord" in Malachi 3:16 where the context consists of the polarity of righteous and wicked within a retribution framework:

Then those who feared/revered the Lord spoke with one another; the book of remembrance was written before him of those who feared/revered the Lord and thought on his name.

As in the Eden story, the so-called Succession Narrative "exhibit the same deterrent attitude to a kind of wisdom which not only promises more than it can deliver but also leads away from traditional religious resources (Blenkinsopp 1992:67). 
The identification of wisdom and torah is implied in the book of Ezra where the letter of Artaxerxes refers interchangeably to:

"the law of God, which is in your hand" (7:14); and

"the wisdom of your God which is in your hand" (7.15).

There is a strong sense of the human tendency towards evil common to both the prophets (Jer 17:9-10) and the sages (Job 14:1-6).

For quite some time similarities between Deuteronomistic and wisdom literature have been noted (Morgan 1981:94).

\subsection{The Torah}

The use of sapiential language in the older version of the creation narrative of Genesis has long been identified by Alonso-Schokel (1962:295-316) in his study of Genesis 2-3. Blenkinsopp (1992:93) is of the opinion that Genesis 1-11 as a whole constitute a reflective commentary by the exiles reflecting on their "fears and hopes" in a sapiential mode. Elsewhere in Genesis the Joseph cycle has been depicted as a sapiential composition by von Rad and Whybray (1968:522-528). Sapiential qualities have been identified in the themes of retribution and divine providence and in the figure of Joseph as a wise administrator (von Rad 1966:292-300).

Without maintaining that Deuteronomy is wisdom literature, a case has been made by Weinfeld (1972a) that the authors responsible for Deuteronomy were associated with the circles responsible for theological perspectives also found in wisdom literature. It would seem as if Deuteronomy reflects a process during which various theological traditions, among them also wisdom traditions, were amalgamated "into a truly nationalistic group of writings" (Morgan 1981:105).

In his research on the origin of apodictic law, Erhardt Gerstenberger (1963:38-51) focused on the wisdom of the clan (Sippenweisheit) and championed the close association of law and wisdom. A similar confluence of wisdom and law is presupposed by Blenkinsopp (1995:151) and he also suggests "that the teaching of the sages entered the mainstream of Israelite religion at the point where it came together with the legal tradition". According to Deuteronomy 4:6 Moses tells the Israelites that "they will show their wisdom and discernment" if they observe the laws and statutes diligently (Collins 1997:54).

I shall now pay special attention to the passages in the book of Exodus where the term "the fear of the Lord/God" occurs:

Exodus 1:17,21 "But the midwives feared God; they did not do as the king of Egypt

commanded, but they let the boys live".

"And because the midwives feared God, he gave them families."

The typical source critical argument that Exodus 1:5-21 should be attributed to the Elohist due to the use of Elohim is obviously weak and has been dealt with conclusively. Werner Schmidt $(1988: 17,22)$ and Joseph Scharbert $(1987: 15)$ are the most recent commentators on Exodus that still insist on the identification of an E source in this particular passage and this is pertinent since the "fear of God" is seen as one of the expressions characteristic of the socalled Elohist.

It is more significant, for the purpose of this discussion, that there is a probably terminological and topical continuity in terms of the increase ( $r b h)$ and strength ('sm) of the Israelites as indicated in 1:7 and 20 (van Seters 1994:23). Furthermore, one should take note that $j r$ ' ("fear") plays an important role in the preceding Joseph cycle (Gen 24:18; 
50:17-20) and that the topical continuity also links the books of Genesis and Exodus (Davies 1992:77).

Several researchers agree about the concentric and chiastic patterns in the compositional structure of Exod 1:15-22 (Exum, Siebert-Hommes, GF Davies). It is striking that the "midwives" are referred to seven times whilst elohim is used three times sin 1:15-21. The expression yar 'e et haelohim is also used by Joseph (42:18) and Nehemiah (7:2).

By and large I agree with Peter Weimar (1997:179-208) that the final redaction of Exodus 1:1-2:10 shaped a compositional unit which was intended as an introduction to the book of Exodus. This beginning of Exodus links up with the conclusion of the book of Genesis and it introduces the "programme" of the rest of the book of Exodus. Besides the themes of the juxtaposition of life and death, which overlaps with the conflict between Pharaoh/gods of Egypt and Moses/Yahweh, I would like to add the motif of the "fear of God" as indicative of the experience of God amidst what Weimar (1997:194) calls the "Gottesschweigen" (experience of the absence of God?). There also seems to be a striking element of irony in this particular narrative: the fear of the Egyptians about the rapid increase of the oppressed Israelites is contrasted with the fear of the midwives; whilst the fear of the midwives lead them to non-action (disobedience) it allows for God's action (the saving of the babies) to take place (Davies 1992:73).

Commentators usually interpret the term "fear of God" as being of ethical significance and Gordon Davies (1992:75) agrees that the "fear of God" amounts to "a moral concept" and "an ethical stance". Rita Burns (1983:30) provides a good example of how this moral definition of the "fear of God" is applied in Exodus 1:15-22: "Persons who feared God were those who acted according to a moral imperative. The wise were those who feared God, who not only discovered this order but who also brought their actions and lives into harmony with it". Nahum Sarna (1991:7) depicts the defiant behaviour of the midwives as "history's first recorded act of civil disobedience in defence of a moral imperative". (Possible echoes of Kantian ethics?)

Due to the general introductory function of Exodus 1-2, I would hesitate to confine the "fear of God" to matters ethical and would like to argue that modern distinctions between ethics and theology did not apply to the hermeneutic frame of reference of the editors of Exodus.

The positive reaction of God towards the "God-fearing" midwives in 1:20, "So God dealt well with the midwives..." might reflect a point of view shared by the wisdom authors of Proverbs 14:27 and 29:23 (Houtman 1993:259). The promise of progeny, which is indicated by Werner Schmidt (1988:460 as the theme "Mehrung", is linked with the "fear of God" and this seems to be a point of view mutually adhered to by the authors/redactors of Genesis, Exodus and Proverbs. Brevard Childs (1974:13) also explains the unusual features of this birth story "in reference to wisdom literature."

Although it complicates the argument to some extent, it must also be taken that the assumption that the fear of God brings about blessing can be found in Deuteronomy 6:24:

"Then the Lord commanded us to observe all these statues, to fear the Lord our God, for our lasting good, so as to keep us alive..."

- Exodus 2:14 Moses fears his fellow Hebrew.

- Exodus 3:6 "He said further, I am the God of your father, the God of Abraham, the God of Isaac, and the God of Jacob. And Moses hid his face, for he was afraid to look at God." 
In a very stimulating article on Exodus 3, Robert Carroll (1994:39-58) finds it problematic that divine presence is simply assumed in the story of the burning bush. The ambivalent opacity of the divine name "I am who I am" or "I will be who I will be" is interpreted as a deliberate evasion of presence in the Exodus 3 narrative. He concludes that the divine "I" of the text cannot be seen by the eye of the reader since in the divine absence created by the biblical text, all divine presence is deferred to a future not yet realized in time. I am not convinced that Ex 3 can be divorced from the rest of Exodus, where we do find strong references to presence.

- Exodus 9:20,30 "Those officials of Pharaoh who feared the word of the Lord hurried their slaves and livestock off to a secure place."

"But as for you and your officials, I know that you do not yet fear the Lord God."

- Exodus 14:10 Israelites are terrified of the Egyptians in hot pursuit.

- Exodus 14:13 Moses commands the Israelites not to be afraid.

- Exodus 14:31 "Israel saw the great work that the Lord did against the Egyptians. So the people feared the Lord and believed in the Lord and in his servant Moses."

G Davies (1992:75) pointed out the word play between $j r$ ' and $r$ ' $h$ (fear and see). This constitutes a change from "fright" to "veneration" and we have here a good example of a powerful/striking image of God as the mysterium tremendum; the source of fear as overwhelming awe. I agree with G Fisher (1996:159): "Ex 14:1-3 "haben als eine Funktion, die in 7:5 angesagte Gotteserkenntnis der Ägypter zu erfüllen”.

- Exodus 15:11 "Who is like you o Lord, among the gods?

Who is like you, majestic in holiness, awesome in splendour, doing wonders?"

These references to the "fear of Israel" for the Egyptians and the Lord God have usually been linked with the Deuteronomic concept of the "holy war". JL Ska (1983) rightly criticized this generalization by pointing to the following:

- The Israelites are not depicted as combatants, as in most examples of a "holy war".

- The Israelites do not follow up the victory with the extermination (or at least the pillage) of the enemy.

- Exodus 18:21: "You should also look for able men among all the people, men who fear God, are trustworthy, and hate dishonest gain; set such men over them as officers over thousands, hundreds, fifties and tens."

Among Pharaoh's advisers were professional wise men (hartūmmê misrayim - Gen. 41:8; Exod 7:11) but there is no such office amongst the Israelites. Exod 8:3 [7] and 15:19 and 9:11 have hartümim, which seems to be a more inclusive term and implies that the wise were numbered among them. In Exod 7:20,30 ebed (servant, official) is used.

- Exodus 20:20 "Moses said to the people, Do not be afraid; for God has come only to test you and put the fear of him upon you so you do not sin."

- Exodus 34:10 "and all the people among whom you live shall see the work of the Lord; for it is an awesome thing that I will do with you."

- Exodus 34:30 "When Aaron and all the Israelites saw Moses, the skin of his face was shining, and they were afraid to come near him." 


\section{Conclusion}

Joseph Blenkinsopp (1992:vii,ix) suggested that the "final decade of the century would seem to be a good time to assess what has been achieved in the study of the Pentateuch" and that in Pentateuchal criticism "theological interpretation lagged behind the critical analysis of texts..." I am convinced that the theological input of sapiential reflection, and in certain instances even full-blown wisdom theology, should be taken into serious consideration to come to a more comprehensive understanding of the process that contributed to the theological coherence of the book of Exodus and of the Pentateuch and the Hebrew Bible as a whole.

I agree with Gerald Sheppard's (1980:159) conclusion that "the search for wisdom's definition and religious significance is a part of the process of canonization which selected and shaped traditions into sacred biblical books and collections." To a lesser degree I concur with Sheppard's (1980:159) other conclusion "that wisdom was assumed to have a hermeneutic function in the context of the canon and that it offered a model for the interpretation of other biblical narrative, prophetic, and hymnic texts as a guide to the obedient life." This seems to disallow wisdom to make a theological contribution, as if sapiential reflection must almost exclusively be evaluated on an ethical level - as the research history of the concept "fear of God" clearly illustrates.

Although Statius proclaimed Primus in orbe deos fecit timor ("At the beginning of the world, fear created the gods"), I would like to suggest that the post-exilic experience of God was expressed by means of the concept "the fear of God/the Lord" which reflected the dialectic understanding of the presence and absence of God. This dialectic understanding of God influenced the combination of existing theological traditions (Deuteronomistic \& Priestly) in the book of Exodus and it contributed to the canonical process during which the Torah, Nebiim and Ketubim achieved the required theological coherence to be understood as a whole.

\section{BIBLIOGRAPHY}

Alonso-Schokel, L 1962. Motivos sapienciales y de alianza en Gn 2-3. Bib 43, 295-316. Balentine, S 1983. The Hidden God: The hiding of the face of God in the Old Testament. Oxford: Oxford University Press.

Becker, J 1965. Gottesfurcht im Alten Testament (AnBib 25). Rome: Pontifical Institute. Blenkinsopp, J 1992. The Pentateuch. London: SCM.

Blenkinsopp, J 1995. Wisdom and Law in the Old Testament. (2 ed.) Oxford: Oxford University Press.

Brekelmans, C 1990. Wisdom influence in Deuteronomy, in La Sagesse de L'Ancien Testament (ed.) Gilbert, M. Leuven: University Press, 28-38.

Brueggemann, W 1976. Presence of God, Cultic. IDBSupp. 680-683.

Cairns, I 1992. Word and Presence: A Commentary on the Book of Deuteronomy (ITC). Grand Rapids: Eerdmans.

Campbell, AF and O'Brien, MA 1993. Sources of the Pentateuch. Texts, introductions, annotations. Minneapolis: Fortress.

Carroll,RP 1994. Strange fire: Abstract of presence absent in the text. Meditations on Exodus 3. JSOT 61, 39-58.

Childs, BS 1974. Exodus (OTL). London: SCM. 
Clements, RE 1972. Exodus (CBCNEB). Cambridge: Cambridge University Press.

Clements, RE 1992. Wisdom in Theology. Grand Rapids: Eerdmans.

Clifford, RJ 1972. The Tent of El and the Israelite Tent of Meeting. CBQ 33, 221-227.

Collins, JJ 1997. Jewish Wisdom in the Hellenistic age (OTL). Louisville: Westminster/John Knox.

Crenshaw, JL 1969. Method in Determining Wisdom Influence upon 'Historical' Literature. JBL 88, 129-142.

Davies, GH 1962. Presence of God. IDB 3, 874-875.

Dell, KJ 1997. On the Development of Wisdom in Israel, in Congress Volume Cambridge 1995 (SVT 66), ed. Emerton, JA. Leiden: Brill, 135-151.

Dozeman, TB 1989. God on the Mountain. A Study of Redaction, Theology and Canon in Exodus 19-24 (SBL Mon 37). Atlanta: Scholars Press.

Dozeman, TB 1989. God at War. Power in the Exodus Tradition. New York: Oxford University Press.

Durham, JI 1987. Exodus (Word). Waco: Word.

Eichrodt, W 1967. Theology of the Old Testament Vol 2. London: SCM.

Fensham, FC 1970. Exodus (POT). Nijkerk: Callenbach.

Fischer, AA 1997. Skepsis oder Furcht Gottes? Studien zur Komposition und Theologie des Buches Kohelet (BZAW 247). Berlin: de Gruyter.

Fox, MV 1997. What the Book of Proverbs is About, in Congress Volume Cambridge 1995 (SVT 66), ed. Emerton, JA. Leiden: Brill, 153-167.

Fretheim, TE 1991. Exodus (Interpretation). Louisville: Westminster.

Gerstenberger, E 1963. Covenant and Commandment. JLB 84, 38-51.

Gorman, FH 1997. Divine Presence and Community. A Commentary on the Book of Leviticus (ITC). Grand Rapids: Eerdmans.

Gowan, D 1994. Theology in Exodus: Biblical Theology in the form of a commentary. Louisville: Westminster.

Haspecker, J 1967. Gottesfurcht bei Jesus Sirach: Ihre religiöse Struktur und ihre literarische und doktrinare Bedeutung (AnBib 30). Rome: Pontifical Bible Institute.

Herrmann, S 1992. Weisheit im Bundesbuch. Eine Miszelle zu Ex 23,1-9, in Preuss F/S, 56-58.

Houtman, C 1993. Exodus I (HCOT). Kampen: Kok.

Houtman, C 1994. Der Pentateuch. Die Geschichte siner Erforschung neben einer Auswertung (CBET 9). Kampen: Kok Pharos.

Janzen, JG 1997. Exodus (WBC). Louisville: Westminster/John Knox.

Jeremias, J 1976. Theophany in the OT. IDBSupp, 896-898.

Levine, BA 1974. In the Presence of the Lord. Leiden: Brill.

Mann, TW 1977. Divine Presence and Guidance in Israelite Traditions: The Typology of Exaltation. Baltimore: John Hopkins University Press.

Marbock, J 1971. Weisheit im Wandel: Untersuchungen zur Weisheitstheologie bei Ben Sira (BBB 37). Bonn: Hanstein Verlag.

Morgan, DF 1981. Wisdom in the Old Testament Traditions. Oxford: Blackwell.

Murphy, RE 1996. The tree of life. An Exploration of Biblical Wisdom Literature (2 ed.) Grand Rapids: Eerdmans.

Noth, M 1973. Das zweite Buch Mose Exodus (ATD). Göttingen: Vandenhoeck \& Ruprecht. 
Otto, E 1996. Die nachpriesterliche Pentateuchredaktion im Buch Exodus, in Studies in the book of Exodus, Redaction-Reception-Interpretation (ed. Vervenne, M). Leuven: Peeters, 61-111.

Polak, F 1996. Theophany and Mediator: The Unfolding of a Theme in the Book of Exodus, in Studies in the Book of Exodus. Redaction-Reception-Interpretation (ed. Vervenne, M). Leuven: Peeters, 113-148.

Rad, von G 1966. The Problem of the Hexateuch and Other Essays. New York: McGrawHill

Sarna, NM 1986. Exploring Exodus. The Heritage of Biblical Israel. New York: Schocken.

Sarna, NM 1991. Exodus (JPS Torah Com). Philadelphia: Jewish Publication Society of America

Scharbert, J 1989. Exodus (Neue Echter Bibel). Würzburg:

Schmidt, WH 1974. Exodus (BK). Neukirchen-Vluyn: Neukirchener Verlag.

Schmitt, HC 1997. Das spätdeuteronomistische Geschichtswerk. Genesis i - Regum xxv und seine theologische Intention, in Congress Volume Cambridge 1995 (SVT 66), ed. Emerton, JA. Leiden: Brill, 261-279.

Schwenk-Bressler, U 1993. Sapientia Salomonis als ein Beispiel frujudischer Textauslegung: Die Auslegung des Buches Genesis, Exodus 1-15 und Teilen der Wustentradition in Sap 10-19 (BEATAJ 32). Frankfurt: Lang.

Sheppard, GT 1980. Wisdom as a Hermeneutic Construct (BZAW 151). Berlin: de Gruyter.

Skehan, PW \& Di Lella, AA 1987. The Wisdom of Ben Sira (AP). New York: Doubleday.

Smith, MS 1997. The Pilgrimage Pattern in Exodus (JSOTS 239). Sheffield: JSOT.

Talmon, S 1963. Wisdom in the book of Esther. VT 13, 419-455.

Terrien, S 1978. The Elusive Presence: The Heart of Biblical Theology. San Francisco: Harper \& Row.

Van Seters, J 1994. The Life of Moses. The Yahwist as Historian in Exodus-Numbers. Louisville: Westminster/John Knox.

Vervenne, M 1994. The Question of 'Deuteronomic' Elements in Genesis to Numbers, in Studies in Deuteronomy. In honour of CJ Labuschagne on the occasion of his 65th birthday, eds. Garcia Martinez, F, Hillhorst, A, et al. Leiden: Brill, 243-268.

Vervenne, M 1996. Current Tendencies and Developments in the Study of Exodus, in Studies in the Book of Exodus. Redaction-Reception-Interpretation. (ed. Vervenne, M). Leuven: Peeters 21-59.

Weimar, P 1996. Exodus 1,1-2,10 als Eroffnungskomposition des Exodusbuches, in Studies in the book of Exodus. Redaction-Reception-Interpretation (ed. Vervenne, M). Leuven: Peeters, 179-208.

Weinfeld, M 1972a. Deuteronomy and the Deuteronomic School. Oxford: Oxford University Press.

Weinfeld, M 1972b. Presence, Divine. Enc Jud 13, 1015-1020.

Wenham, G 1996. Pentateuchal Studies Today. Them 22, 3-13.

Whybray, RN 1968. The Joseph Story and Pentateuchal Criticism. VT 18, 522-528.

Whybray, RN 1995. Introduction to the Pentateuch. Grand Rapids: Eerdmans.

Wilson, I 1996. Out of the Midst of the Fire. Divine Presence in Deuteronomy (SBL Diss 151). Atlanta: Scholars Press. 